This Section of Epidemiology and Psychiatric Sciences appears in each issue of the Journal and is dedicated to all forms of creative production born of an intimate and individual urge, often secretive, unbound from the conventional art system rules. Through short descriptions of the Outsider art work of prominent artists and new protagonists often hosted in community mental health services, this section intends to investigate the latest developments of the contemporary art scene, where the distances between the edge and the center are becoming more and more vague.

Carole Tansella, Section Editor

\title{
Vincenzo Sciandra's multiple identity
}

\section{Tansella}

Department of Time, Space, Image, Society, University of Verona, Verona, Italy

Received 12 February 2013; Revised 12 March 2013; Accepted 12 March 2013; First published online 16 April 2013

Key words: art brut, contemporary aesthetic, Outsider art, self-taught art.
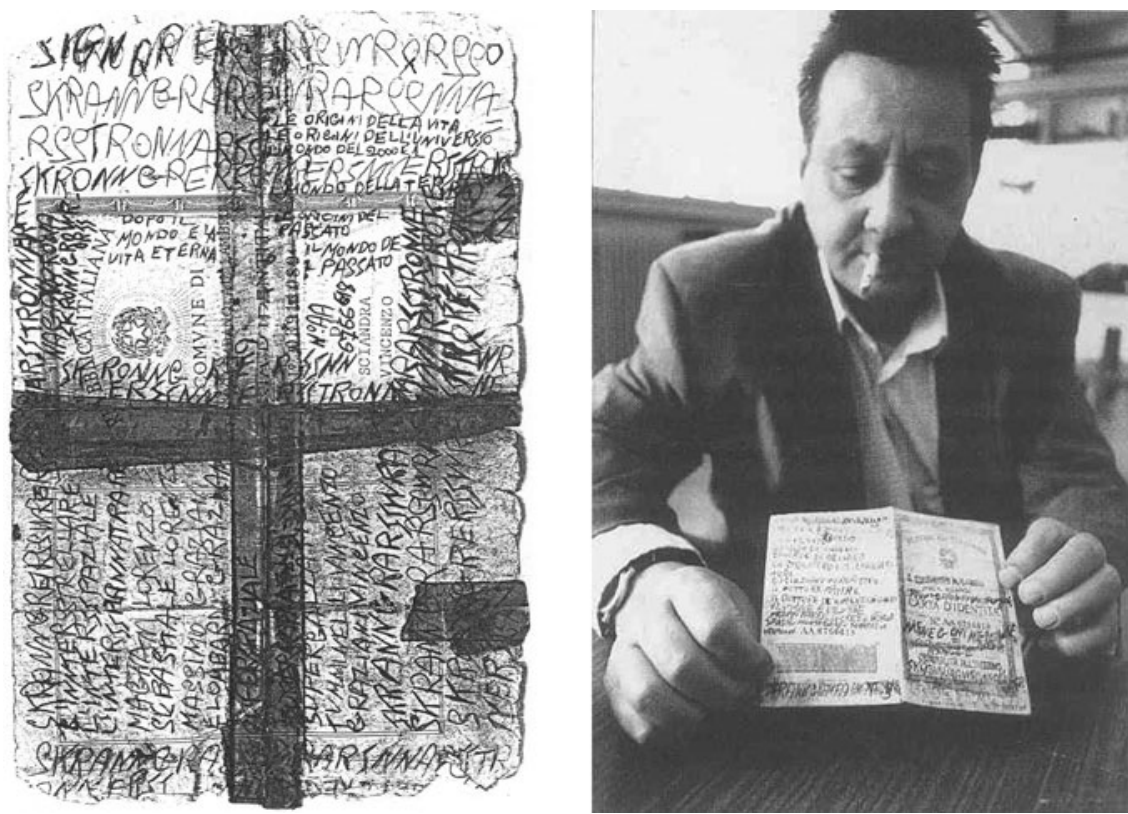

Vincenzo Sciandra: Untiteled, Mixed media, 1998.

Since its origins in the 20th century, Outsider art has always been a global phenomenon (Rhodes, 2012), difficult to define with a clear stylistic label. It was born in

Address for correspondence: Dr Carole Tansella, Department of Time, Space, Image, Society, University of Verona, Via San Francesco 22, 37129 Verona, Italy.

(Email: carole.tansella@yahoo.it; carole.tansella@univr.it) asylums through the action of self-taught artists, and it now includes works created by people who suffered from a multiplicity of conditions. The common feature of all Outsider art productions is its independence from the official art system, which is often due to the artists' indifference to this world, but also to the difficulty they experienced in accessing the traditional channels of training, production and art consumption. Nowadays, 
Outsider art's spaces of practice and production have become a reality, growing ceaselessly all over the world. In Italy, one of the most famous organizations is Atelier Adriano e Michele, founded in 1996 at the psychiatric rehabilitation centre Fatebenefratelli in San Colombano al Lambro, in Milan. In this issue of EPS, we chose to outline the critical sketch of Vincenzo Sciandra, a historic artist of Atelier Adriano e Michele, as a starting point to examine the present development of the art that was born in treatment centres after the shutdown of mental institutions. Few facts about the artist's life are known. Between 1983 and 2006, the year when he died (Tosatti, 1997), he lived at Hospital Fatebenefratelli of San Colombano al Lambro, and from 1996, he was permanently involved in the activity of Atelier Adriano e Michele. All the other data reported by the author are to be considered untrustworthy and cannot be used to make a truthful reconstruction of his biography; the issue of identity is indeed the very cornerstone of the artist's own poetics. Especially in his first works, Sciandra used his identity card and customized it by writing on it disorganized fragments of prose and poetry, long lists of names that he had drawn from the news, from literature and comics or that he had completely made up. The work carried out by this artist is a 'squared', 'gentle' genre of performance (Tansella, 2011). The 'visual sounds scratched out with unpronounceable letters' (Bedoni \& Tosatti, 2000) are pushing each other to release them beyond the margin of the document and seem to share the same ritual obsession of voodoo practices. Sciandra's swerve, compared with the performances of the sixties and seventies, is made in terms of lightness, not a conceptual, but a material one. The elimination of the author's effective body presence from the action field and its substitution with its projections on the document, releases the operation from violent and provocative charge, typical of the early days of the Body art movement. The boundless, anarchic writing of names highlights the fragility of that unique piece of paper, to which we commit the official certification of our uniqueness and existence. Bobby Sands, Gagarin, Sandro Skarlatta, Skillinger, Clark Kent, Lombardini Angelo and all the others, considered as the author's doppelgängers or alter egos, are all demanding the same right to exist. Image and word meet in Sciandra's papers, finding a new variation compared with the early 20th century solutions and proving that the history of art always recurs cyclically, although never with the same pattern.

\section{References}

Bedoni G, Tosatti B (2000). Arte e Psichiatria. Uno Sguardo Sottile. Mazzotta: Milano.

Rhodes C (2012). The European Outsider Art Association. In On the Map. Exploring European Outsider Art. A Notebook. Museum Dr. Guislain: Ghent, Belgium.

Tansella C (2011). Dai margini al centro e ritorno. Nuovi aspetti dell'Art Brut dall'Atelier di pittura Adriano e Michele. In Un Lungo Percorso dal Medioevo a Oggi. Annuario della Scuola di Specializzazione in Beni Storici Artistici, n. 8, Università di Bologna, Bonomia University Press: Bologna.

Tosatti B (1997). Carlo con Adriano e Michele: Immagini dell'Altro Mondo. Catalogo della mostra: Lodi. 